DOI 10.31392/NPU-nc.series15.2021.11(143).01

\author{
Gavrilova N. \\ senior lecturer at the Department of Health and Sports Technologies \\ Mokhunko 0. \\ senior lecturer at the Department of Health and Sports Technologies \\ National Technical University of Ukraine Igor Sikorsky Kyiv Polytechnic Institute
}

\title{
ORGANIZATION OF PHYSICAL CULTURE AND SPORTS ACTIVITIES OF STUDENTS IN THE PROCESS OF JUDO CLASSES
}

The article analyzes the features of the organization of physical culture and sports activities of student youth during judo classes. The state of physical culture and sports activities in the conditions of distance learning during the coronary virus pandemic is revealed. It is determined that judo classes are the most popular among students, which significantly increases their level of motivation to exercise. It was found that the optimization of physical culture and sports has a positive effect on improving the mental and physical condition and health of those involved. It is established that the need to organize physical culture and sports activities of students in the process of judo is due not only to the demands and rights of students, age, developmental conditions, constantly changing, but also the social order of society to form a healthy generation.

However, the development of these innovative processes is constrained due to insufficient software and methodological support for new forms of physical education, as existing sports training programs for children and adolescents are focused on the preparation of sports reserves and are not designed for mass use in secondary school.

However, the development of these innovative processes is constrained due to insufficient software and methodological support for new forms of physical education, as existing sports training programs for children and adolescents are focused on the preparation of sports reserves and are not designed for mass use in secondary school.

Key words: physical education, judo, physical culture and sports activity, physical exercises, students.

Гаврилова Н., Мохунько О. Організація фізкультурно-спортивної діяльності студентів у процесі занять дзюдо. В статті проаналізовано особливості організації фізкультурно-спортивної діяльності студентської молоді під час занять з дзюдо. Розкрито стан фізкультурно-спортивної діяльності в умовах дистанційного навчання під час пандемії корона вірусу. Визначено, заняття з дзюдо користуються найбільшою популярністю серед студентства, що значно підвищує їх рівень мотивації до занять фізичними вправами. Виявлено, що оптимізація фізкультурно-спортивної діяльності позитивно впливає на покращення психорізичного стану та рівень здоров'я тих, хто займається. Встановлено, що необхідність організації фізкультурно-спортивної діяльності студентів у процесі занять дзюдо зумовлена не лише запитами та правами особистості школярів, віковими особливостями їх розвитку, умовами життєдіяльності, що постійно змінюються, а й соиіальним замовленням суспільства на формування здорового покоління.

Ключові слова: фізичне виховання, дзюдо, фізкультурно-спортивна діяльність, фізичні вправи, студенти.

Formulation of the problem. Physical culture in higher education is presented as an academic discipline and the most important component of the holistic development of the student's personality, the importance of which is manifested through the harmonization of spiritual and physical strength, the formation of universal values such as health, physical and mental well-being, physical perfection.

The attitude of students to physical culture and sports is one of the current socio-pedagogical problems of the educational process, further development and expansion of mass health, physical culture and sports work in higher education. The implementation of this task should be considered from two positions - as personally significant and as socially necessary. In the conditions of higher school activity the work on activation of a position of each student concerning the physical development and preparation, real participation in various forms of physical culture and sports activity is fundamentally important.

In modern society, there have long been problems of economic, social, moral nature for most young people were limited opportunities for sports. The reduction and shortage of sports facilities, existing sports sections, clubs, accessible to a large number of all age groups involved, has led to the fact that only a small part of the population is currently involved in physical culture and sports activities.

Analysis of literature sources. The long-term trend of deteriorating health of student youth, noted by experts, entails a further decline in health in all age groups and further affects subsequent generations. Most students are poorly informed about the real state of their health. There is no personal responsibility of the vast majority of students, as well as the entire population for their own health, not only to themselves but also to society.

The problematic situation in the system of physical education of the younger generation in our country is due to the contradiction that has arisen today, while on the one hand one of the leading principles of state educational policy is the humanistic orientation of education, which determines the priority of universal values. comprehensive development of personality on the basis of personality-oriented approach, and on the other - modern pedagogical science does not provide a new scientific, theoretical and methodological knowledge that can provide innovative transformations in the organization of physical education in secondary school with modern requirements for health and fitness students, to the level of their physical and sports culture 
Meanwhile, despite the already known technologies of highly effective processes of sports training, these methods and conceptual approaches have not found a conversion continuation in modern theory and practice of physical education [9]. These circumstances necessitate the development of new organizational forms of physical education, which allow to master in practice high technologies of sports training and organization of sports activities.

A critical situation was observed in the creation of student sports. Many universities in the country did not have the opportunity to maintain sports clubs. The calendar of student competitions has sharply decreased, the number of students resting in sports and health camps has decreased. This requires a solution to the problem of improving the effectiveness of physical education and the development of student sports at a new socio-cultural level. According to the scientific works of Yu. Belyak (2011), V. Sosina, A. Nakonechna (2010), Yu. Usachova, V. Zinchenko, V. O. Zhukova, P. Kozubeya (2011), popular among modern youth is health aerobics, which, due to the emotional background and the use of simple and affordable dance and gymnastic exercises, has a positive effect on the body: strengthens the cardiovascular and respiratory systems, increases aerobic capacity, develops strength, flexibility, coordination of movements, improves general and strength endurance, helping to increase the level of physical fitness [3]. In view of this, the optimization of physical activity, as the main factor in improving the health of students, through the use of health fitness is relevant and socially important. And although fitness is a young type of exercise, it is developing very rapidly, which leads to the study of the problem of individualization of health fitness programs.

Presentation of the main material of the study. Student sports refers to the mass forms of organization of physical exercises. The purpose of mass sports is to strengthen the health of the people, to cultivate positive moral qualities, to organize a healthy lifestyle and to solve various social problems. Mass sports have a largely health effect.

Recently, there has been a change in the attitude of the population to various forms of exercise. From a simple and clear system of motor activity, sport has grown into one of the most important social phenomena, which is quite difficult to assess in general. The meaning of the phenomenon of "sport" has expanded significantly and includes the concepts of play, exercise and a healthy lifestyle. We notice that simple motor activity takes up more and more space and how many concepts are related to sports. The sport is used in the context of yoga, special breathing exercises, morning jogging and hiking, and has become a traditional game and sport. The availability of sports has expanded significantly. Sport has a function to limit the number of people involved in drug addiction, alcoholism, vagrancy and crime. We can safely say that the traditional pyramid, which was based on mass sports, but at the top of a small group of experts, is now destroyed. We consider sport in its diversity: as a professional sport, sport, sport outside of organized competitions, sport as a means of education, sport as a means of rehabilitation. Sport provides unique opportunities for educational work, which captures the prospect of self-improvement.

Abroad, the "Sports for All" movement has developed very widely. Huge funds are invested in these programs, sports facilities are being built. In many countries, student sports are the basis of national sports policy, a kind of "core" of Olympic sports. Social, legal, economic and organizational principles of activity in the field of student sports in many countries are regulated by state, regional laws and regulations. Physical education is a mandatory and full-fledged discipline in the curricula of universities and colleges. It promotes good health, comprehensive physical and moral development, stimulates the process of social adaptation, acquaintance with various forms of exercise.

The study of physical culture in higher education institutions is based on legislative acts approved by the Verkhovna Rada of Ukraine. The purpose of our study is to analyze the relevant legislation, as well as manuals of various educational institutions of Ukraine, which will help determine the role of physical culture in modern education. Particular attention will be paid to higher education institutions, as the organization of the process of physical education in universities and other higher education institutions differs significantly from the organization of the school process due to various factors, including the age difference between students and pupils. First of all, we would like to analyze the legislation that approves the study of the subject in higher education. For example, Article 26 "Physical culture in the field of education" of the relevant law describes only the study of physical culture in higher education. According to her, physical culture is a compulsory subject [1]. At the same time, persons belonging to the rehabilitation group must also be present at practical classes, but must perform only those exercises that have been approved by the relevant medical institution and do not require excessive physical activity. Thus, we can see that the legislation provides for different levels of workload for different categories of students depending on their physical condition. Article 26 describes in detail the purpose of physical culture, emphasizing that, above all, it is to ensure motor activity, which is important for the harmonious development of personality [1]. In addition, we can also highlight the following functions of physical culture, which were analyzed, including in the collections of various educational institutions dedicated to physical culture as a subject: - preparation for active life, which involves the need to be mobile and adapt to rapid change; - the formation of not only mental abilities of the individual, but also physical; - health function (formation of immunity and general prevention). This point can be considered especially important now, due to the impact of new diseases, and in particular COVID-19; - switching activities from mental to physical, which helps to relax and prepare for the assimilation of new material; - the opportunity to express themselves as an active person, taking part in various competitions or other sports.

This work also analyzes the problem of so-called "extracurricular" physical activity of students, ie one that is not conducted in classrooms and sports grounds of the university, but involves the student's own initiative to engage in physical culture after classes. An important function of physical education is to help the student understand how sports and exercise can positively affect his life. To do this, special teaching methods need to be developed in order to teach what physical activities can and should be carried out during extracurricular physical education classes [3]. We believe that this can be influenced by a number of factors, including the availability of sports equipment that students can use after classes, or the organization of sections that will help to understand what "team spirit" is and will serve as a motivator for students.

Teamwork is also very important, as rivalry based on self-improvement and the support of others can affect the desire to exercise. Teams and sections have a positive impact not only on the physical development of the student, they also contribute 
to his social and psychological development, help to find a way out of difficult situations and teach the principles of interaction in society. Thus, we can say that physical culture in higher education also affects the development of students' communication skills. Undoubtedly, school physical education classes also play an important role in the formation of personality, but it is the classes held in higher education institutions that help prepare a person for adult life. Reduction of the network of sports and health facilities, sports clubs, commercialization of sports centers with increasing cost of training and health services led to a decrease in physical activity of various groups of children, development of chronic diseases and progression of physical defects, deterioration of physical fitness.

The problem of physical education of children with various health disorders is still acute and, unfortunately, in many schools is not solved. Such children are simply exempted from physical education, while weakened children need even more beneficial effects on the body of various means of physical culture and sports [2].

The need to promote physical culture and sports among children, adolescents and youth is due not only to the demands and rights of students, age, developmental conditions, constantly changing, but also the "social order" of society to form a healthy generation.

Conclusions. Слід зазначити, що існуючі підходи до вирішення проблеми розвитку фізичної культури та спорту у вузах країни тривалий час були пов'язані переважно з удосконаленням змісту навчально-тренувального процесу спортсменів, що веде до зростання спортивних результатів. Ці підходи фактично спрямовані на обмежену кількість тих, хто займається і не зачіпають вирішення проблем, пов'язаних з розвитком фізкультурно-спортивної діяльності значної маси студентства. Проведення внутрішньо-вузівських та міжвузівських спартакіад з обов'язковим набором традиційних видів спорту $є$ ефективним засобом залучення студентів до фрізкультурно-спортивної діяльності, але охоплює лише частину студентів. Більшість студентської молоді не залучена до фізкультурно-спортивної діяльності. У цій масі приховані невикористані можливості формування індивідуальної мотивації зміцнення здоров'я засобами фрізичного вдосконалення. Завдання закладів вищої освіти активізувати прагнення до самоствердження та особистого пізнання справжніх цінностей фрізичної культури.

1. Bubley T. (2016) Features of planning and organization of physical education lessons for students with impaired health: status and prospects // Scientific Journal. Series 15. "Scientific and pedagogical problems of physical culture (physical culture and sports)". Issue 3K 2 (71) 16. K .: Published by NPU named after M. Drahomanov. 53-55 p.

2. Griban, G., Tymoshenko, O., Arefiev, V., Sushchenko, L., Domina, Zh., Malechko, T., Zhuravlov, I., Tkachenko, P., Baldetskiy, A., Prontenko, K. (2020). The role of physical education in improving the health status of students of special medical groups. Wiadomości Lekarskie, 73 (3), 534-540. doi: 10.36740/WLek202003125.

3. Redkina M. Features of physical health of students which have low motor activity / M. Redkina // The scientific heritage № 46 (4) (2020). - Budapest, 2020. - P. 53-56.

4. Redkina Mariia Features of the using of infocomunication technologies in the process of physical education of modern youth // Materials of II International scientific conference (Kaunas, Lithuania, 22 February 2019). Lithuania, Faculty of Social Vytautas Magnus University. P. 296-298.

5. Shaposhnikova, I., Korsun, S., Arefieva, L., Kostikova, O., Serhiienko, V., Korol, S., Riabchenko, V. (2021). Analysis of students' somatic health and emotional state during sports games classes. Wiadomości Lekarskie, 74 (3 p.II), $608-$ 612. doi: 10.36740/WLek202103208.

6. Tymoshenko, O., Arefiev, V., Domina, Zh., Malechko, T., Bondar, T., Tymchyk, M., Pliushchakova, O., Riabchenko, V., Griban, G., \& Prontenko, K. (2021). Exercise machines in speed and coordination development among students playing basketball. International Journal of Human Movement and Sports Sciences, 9(2), 347-355. doi: 10.13189/saj.2021.090224.

DOI 10.31392/NPU-nc.series15.2021.11(143).02 UDC 796.853.23:37.013

\author{
Shuba Liudmyla \\ Associate Professor, PhD in Pedagogy, \\ Associate Professor of the Physical Culture and Sport \\ Management Department National University "Zaporizhzhia Polytechnic", (Zaporizhzhia Ukraine), \\ Shuba Victoria \\ PhD in Pedagogy, \\ Associate Professor of the Pedagogy and Psychology Department \\ Prydniprovska State Academy of Physical Culture and Sports, (Dnipro, Ukraine)
}

\title{
PHYSICAL TRAINING FOR 7-9 YEAR OLD JUDOISTS
}

Judo is a detailed system of movements that allows you to govern the body as a harmoniously single organism capable of developing the physical abilities and functional fitness of athletes. In the conditions of competitive activity in judo the individual multivariate way of technical and tactical performance in the form of the throws, restraints, painful and suffocating locks is observed. Performing all these techniques requires strength, endurance, instant speed and coordination skills. The purpose of the article is improvement the methods of general and special physical training development for 7-9 year-old judokas. The experimentation facility was Children's and Youth Sports School № 11, Zaporizhia. It was attended by 43 boys aged 7-9 who were divided into control $(n=21)$ and experimental $(n=22)$ groups, all boys were classified in the main medical group. All 